\title{
Syntheses and Properties of Quaternary Cr-Ti-B-N Coatings by a High Power Impulse Magnetron Sputtering Technique
}

\author{
Hee-bok Myoung ${ }^{a, b}$, Teng Fei Zhang ${ }^{a, b}$, Jong-Keuk Park ${ }^{c}$, Doo-In Kim ${ }^{b * *}$, \\ Kwang Ho Kim ${ }^{\mathrm{a}, \mathrm{b} *}$ \\ ${ }^{a}$ School of Materials Science and Engineering, Pusan National University, Busan 609-735, Korea \\ ${ }^{\mathrm{b}}$ National Core Research Center for Hybrid Materials Solution, Pusan National University, \\ Busan 609-735, Korea \\ ${ }^{\circ}$ Electronic Materials Center, Korea Institute of Science and Technology, Seoul 130-650, Korea
}

(Received November 6, 2012 ; revised November 26, 2012 ; accepted December 30, 2012)

\begin{abstract}
Cr-Ti-B-N coatings were synthesized by a hybrid coating system combining high power impulse magnetron sputtering (HIPIMS) and DC pulse magnetron sputtering from a $\mathrm{TiB}_{2}$ and a $\mathrm{Cr}$ target in argon-nitrogen environment, respectively. By changing the power applied on the $\mathrm{Cr}$ and $\mathrm{TiB}_{2}$ cathodes, the Cr-Ti-B-N coatings with various $\mathrm{Ti} / \mathrm{Cr}$ ratio and $\mathrm{B}$ content were deposited. The phase structure, microstructure and chemical compositions of the Cr-Ti-B-N coatings were studied by X-ray diffraction (XRD), transmission scanning electron microscopy (TEM), and X-ray photoelectron spectroscopy (XPS). With increase of Cr element in the coatings, the nanocomposite microstructure consisting of nano-sized $(\mathrm{Cr}, \mathrm{Ti}) \mathrm{N}$ crystallites and amorphous $\mathrm{BN}$ phase were obtained in the coatings. The microhardness of the Cr-Ti-B-N coatings exhibited a peak value of $\sim 41 \mathrm{GPa}$ for the $\mathrm{CrTi}_{0.1} \mathrm{~B}_{0.4} \mathrm{~N}_{1.3}$, and then decreased with further increase of $\mathrm{Cr}$ content in the coatings, and all the coatings exhibited low friction coefficient. The oxidation and corrosion behavior of the $\mathrm{Cr}-\mathrm{Ti}-$ B-N coatings revealed better properties due to the formation of a nanocomposite microstructure.
\end{abstract}

Keywords: HIPIMS, Cr-Ti-B-N coatings, Nanocomposite, Friction, Anti-corrosion

\section{Introduction}

To increase the lifetime and performance of cutting and forming tools, there are increasing demands for coatings with improved mechanical or thermal properties, which requires the development of new coating materials and new synthesis methods. The Bcontaining coatings are attracting significant attentions because of their high hardness and other good properties. For example, $\mathrm{TiB}_{2}$ and $\mathrm{CrB}_{2}$ are well known for their superhardness ${ }^{1-6)}$ and a $\mathrm{CrB}_{2}$ is excellent oxidation resistance up to $900^{\circ} \mathrm{C}$ in ambient air $^{7}$. By adding boron element into a growing TiN or $\mathrm{CrN}$ coating, nc-TiN/a-BN ${ }^{8-11)}$, nc-TiN/a-TiB ${ }_{2}{ }^{12,13)}$, nc$\mathrm{CrN} / \mathrm{a}-\mathrm{BN}^{14-17)}$, or nc- $\mathrm{CrB}_{2} / \mathrm{a}^{-\mathrm{BN}^{18)}}$ nanocomposite microstructure can be formed. These ternary nano-

\footnotetext{
${ }^{*}$ Corresponding author. E-mail : kwhokim@pusan.ac.kr ${ }^{* *}$ Corresponding author. E-mail : dooin.kim@pusan.ac.kr
}

composite coatings can be tailored to possess excellent properties such as super hardness, high thermal stability, excellent wear and oxidation resistance. Recently, some quaternary or quinary coatings are designed and explored in order to further improve the characteristics of previous ternary coatings using the nanocomposite concepts. For example, Lin et $a l .{ }^{19)}$ and Shtansky et $a .^{20)}$ synthesized Ti-B-C-N, TiCr-B-N, Ti-Si-B-N, and Ti-Al-Si-B-N nanocomposite coatings by reactive sputtering from the Ti-B-C, Ti$\mathrm{Cr}-\mathrm{B}$, Ti-Si-B, and Ti-Al-Si-B composite targets in an $\mathrm{Ar} / \mathrm{N}_{2}$ atmosphere, respectively. The combination of low friction properties, high hardness and strong adhesion strength makes these coatings promising candidates for protective coatings to be used in various tribological applications. Among them, Ti-CrB-N coating exhibited excellent properties, such as high hardness and wear resistance, thermal stability up to $1000^{\circ} \mathrm{C}$, oxidation resistance up to $900^{\circ} \mathrm{C}$, and 
corrosion resistance in $1 \mathrm{~N} \mathrm{H}_{2} \mathrm{SO}_{4}{ }^{21)}$. However, it seems that the relationship between the chemical composition of the Ti-Cr-B-N coatings and their microstructure and properties has not been fully understood yet.

In recent years, high power impulse magnetron sputtering (HIPIMS) technique has been developed as a new physical vapor deposition technique. By applying a very high peak power at the target with a low duty cycle, HIPIMS process, is achieving a high degree of ionization of the sputtered species, which opens significant opportunities for substrate-coating interface engineering and tailoring coating growth and resulting properties. HIPIMS + technique, a variation of HIPIMS technique, is utilizing modulated pulse power (MPP) as cathode power supplies. By using longer and modulated higher power pulses than the conventional HIPIMS pulses, one can obtain a high degree of ionization of the sputtered species with high ion energies, while at the same time achieving reasonable deposition rate. The HIPIMS+ technique can be utilized to obtain dense coatings with high hardness and low-level residual stress. These characteristics make the HIPIMS+ technology desirable in synthesizing hard coatings. $\mathrm{CrN}^{22-25}$, $\mathrm{Cr}_{2} \mathrm{~N}^{25}$, and $\mathrm{CrN} / \mathrm{TiN}^{26)}$ coatings with much improved mechanical properties have been deposited utilizing the HIPIMS+ (or called MPP) technique. However, it seems that no B-containing hard coating by HIPIMS+ technique has been reported.

In this work, synthesis and characterization of quaternary $\mathrm{Cr}$-Ti-B-N coatings were explored using a hybrid coating method of HIPIMS+ and DC pulse sputtering techniques. The objective of the present study is to investigate the feasibility of synthesizing Cr-Ti-B-N coatings by the hybrid HIPIMS + technique and the effects of the chemical composition of the Cr-Ti-B-N coatings on the coating microstructure and their mechanical properties.

\section{Experimental details}

\subsection{Coating deposition}

Cr-Ti-B-N coatings were deposited on polished AISI 304 stainless steel and $<100>$ single crystalline $\mathrm{Si}$ wafer substrates using a hybrid coating system combining a HIPIMS+ and DC pulse sputtering, as shown in Fig. 1. A compound $\mathrm{TiB}_{2}$ cathode source $(99.9 \%)$ was powered by a HIPIMS+ power generator (Hauzer Techno Coating BV) while the Cr (99.99\%) source utilized a DC pulse power. The $\mathrm{TiB}_{2}$ target was synthesized using a one-step SHS (self-propagating high-temperature synthesis) consolidation method at the SHS center of Moscow State Institute for Steel and Alloys.

Before being placed into the chamber for deposition, all the substrates were ultrasonically cleaned in acetone and ethanol for $10 \mathrm{~min}$, respectively, then

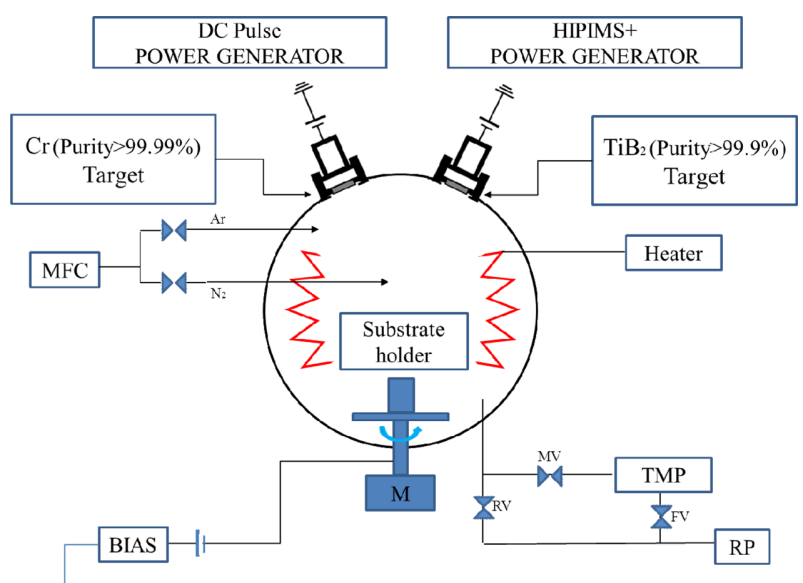

Fig. 1. Schematic diagram of the deposition system.

Table 1. Experiment conditions

\begin{tabular}{|c|c|c|}
\hline Process & Parameters & Range of values \\
\hline \multirow{3}{*}{$\begin{array}{l}\text { Plasma } \\
\text { etching }\end{array}$} & Bias voltage & $-700 \mathrm{~V}$ \\
\hline & Ar pressure & $0.67 \mathrm{~Pa}$ \\
\hline & Time & $10 \mathrm{~min}$ \\
\hline \multirow{4}{*}{$\begin{array}{c}\text { Ion } \\
\text { bombardment }\end{array}$} & Bias voltage & $-600 \mathrm{~V}$ \\
\hline & Ar pressure & $0.67 \mathrm{~Pa}$ \\
\hline & HIPIMS power & $0.6 \mathrm{~kW}$ \\
\hline & Time & $10 \mathrm{~min}$ \\
\hline \multirow{13}{*}{$\begin{array}{c}\text { Film } \\
\text { deposition }\end{array}$} & \multirow{2}{*}{ Target } & $\begin{array}{c}\mathrm{TiB}_{2} \\
\text { (purity }>99.9 \% \text { ); }\end{array}$ \\
\hline & & $\begin{array}{c}\mathrm{Cr} \\
\text { (purity }>99.9 \% \text { ) }\end{array}$ \\
\hline & Substrate & $\begin{array}{c}\text { AISI } 304 \text { steel, } \mathrm{Si} \\
\text { wafer }\end{array}$ \\
\hline & Substrate - target distance & $150 \mathrm{~mm}$ \\
\hline & Base pressure & $<6.67 \times 10^{-3} \mathrm{~Pa}$ \\
\hline & Working pressure & $0.8 \mathrm{~Pa}$ \\
\hline & Deposition temperature & $200^{\circ} \mathrm{C}$ \\
\hline & Bias voltage & $-100 \mathrm{~V}$ \\
\hline & Gas ratio & $\begin{array}{l}\text { Ar : } \mathrm{N}_{2}=5: 3 \\
\text { (Total } 80 \mathrm{sccm} \text { ) }\end{array}$ \\
\hline & \multirow{2}{*}{ Sputter power } & $\begin{array}{c}\text { HIPIMS } \\
(0-0.8 \mathrm{~kW})\end{array}$ \\
\hline & & $\begin{array}{l}\text { DC pulse } \\
(0-0.8 \mathrm{~kW})\end{array}$ \\
\hline & Deposition rate & $\sim 3.5 \mu \mathrm{m} / \mathrm{hr}$ \\
\hline & Deposition time & $1 \mathrm{hr}$ \\
\hline
\end{tabular}


Table 2. The HIPIMS pulsing parameters for Cr-Ti-B-N coatings deposition

\begin{tabular}{|c|c|c|c|c|c|c|c|c|}
\hline $\begin{array}{c}\text { Pulsing } \\
\text { parameters }\end{array}$ & $\begin{array}{c}\mathrm{P}_{\mathrm{a}} \\
{[\mathrm{kW}]}\end{array}$ & $\begin{array}{c}\mathrm{P}_{\mathrm{p}} \\
{[\mathrm{kW}]}\end{array}$ & $\begin{array}{c}\mathrm{I}_{\mathrm{a}} \\
{[\mathrm{A}]}\end{array}$ & $\begin{array}{c}\mathrm{I}_{\mathrm{p}} \\
{[\mathrm{A}]}\end{array}$ & $\begin{array}{c}\mathrm{V}_{\mathrm{a}} \\
{[\mathrm{V}]}\end{array}$ & $\begin{array}{c}\mathrm{V}_{\mathrm{p}} \\
{[\mathrm{V}]}\end{array}$ & $\begin{array}{c}\text { Repetition } \\
\text { Frequency }[\mathrm{Hz}]\end{array}$ & $\begin{array}{c}\text { Peak current } \\
\text { density }\left[\mathrm{A} / \mathrm{cm}^{2}\right]\end{array}$ \\
\hline \multirow{3}{*}{$\mathrm{TiB}_{2}$} & 0.8 & 22.7 & 19.4 & 48.7 & 428 & 467 & 67 & 0.97 \\
\cline { 2 - 9 } & 0.6 & 16.1 & 14.6 & 34.1 & 441 & 472 & 83 & 0.68 \\
\cline { 2 - 9 } & 0.2 & 5.3 & 7.7 & 10.7 & 480 & 500 & 112 & 0.21 \\
\hline
\end{tabular}

$-\mathrm{P}_{\mathrm{a}}$ and $\mathrm{P}_{\mathrm{p}}$ are the average and peak target power.

$-I_{a}$ and $I_{p}$ are the average and peak target current in one pulse length.

$-\mathrm{V}_{\mathrm{a}}$ and $\mathrm{V}_{\mathrm{p}}$ are the average and peak target voltage.

blown dry with $\mathrm{N}_{2}$ and put onto the specimen holders. The chamber was evacuated to a base pressure below $5.0 \times 10^{-3} \mathrm{~Pa}$ using a rotary and turbo molecule pump. Before deposition, plasma etching was conducted by Ar glow discharge for 5 min with a DC bias of $-800 \mathrm{~V}$ at an Ar gas atmosphere of $0.8 \mathrm{~Pa}$. Then ion bombardment was conducted by the pulse DC sputter discharge of the $\mathrm{Cr}$ target for $5 \mathrm{~min}$ at a bias voltage of $-700 \mathrm{~V}$ in an $\mathrm{Ar}$ gas pressure of $0.8 \mathrm{~Pa}$. Then $\mathrm{Cr}-$ Ti-B-N coatings were deposited by reactive sputtering from $\mathrm{TiB}_{2}$ and $\mathrm{Cr}$ sources in an $\mathrm{Ar} / \mathrm{N}_{2}$ gas atmosphere simultaneously. Typical deposition conditions for $\mathrm{Cr}$ Ti-B-N coatings are summarized in Table 1. The HIPIMS pulsing parameters such as target power and target current are summarized in Table 2. During deposition, the repetition rate of the HIPIMS+ power and duty cycle of the DC pulse power was maintained at $80 \mathrm{~Hz}$ and $60 \%$, respectively. No apparent microarcs were observed during all the deposition processes.

\subsection{Coating characterization}

The coating thickness was measured using a stylus $(\alpha-S T E P)$ profilometer and scanning electron microscopy (SEM, Hitachi, S-4200). The crystal structures of the coatings were analyzed by X-ray diffraction (XRD, D8-Discovery Brucker, $\mathrm{Cu} K_{\alpha}, 40 \mathrm{kV}, 40 \mathrm{~mA}$ ). X-ray photoelectron spectroscopy (XPS, VG Scientifics, ESCALAB 250) was performed to determine the contents of $\mathrm{Cr}, \mathrm{Ti}, \mathrm{B}$, and $\mathrm{N}$ elements in the coatings and to observe the bonding status of the elements. The XPS spectra were obtained after removing the surface layer of samples by sputtering with $\mathrm{Ar}^{+}$ions $(3 \mathrm{keV}$ ) for $3 \mathrm{~min}$, and were calibrated for the value of carbon peak C $1 s$ at $284.5 \mathrm{eV}$. Structural information on the coatings was also obtained from the transmission electron microscopy (TEM) observations using a field emission transmission electron microscope (FE-TEM, JEOL, JEM-2012F) with a $200 \mathrm{kV}$ acceleration voltage. The hardness of coatings was evaluated using a microhardness tester with Knoop indenter (Matsuzawa, MMT-7) under a load of $25 \mathrm{~g}$. The friction coefficient and wear behavior were evaluated through sliding tests using a ball-on-disc wear apparatus. A steel ball (diameter $6.34 \mathrm{~mm}, 700 \mathrm{Hv} 0.2$ ) was used as a counterpart material. The sliding tests were conducted with a sliding speed of $0.157 \mathrm{~m} / \mathrm{s}$ under a load of $5 \mathrm{~N}$ at ambient temperature (around $20^{\circ} \mathrm{C}$ ) and relative humidity $(25-30 \% \mathrm{RH})$ condition. Scanning electron microscopy was employed to observe the morphology of the wear track after each sliding experiment.

\subsection{Oxidation and corrosion tests}

Isothermal oxidation tests were conducted in static air in a muffle furnace by heating the $\mathrm{Si}$ wafer specimens coated with Cr-Ti-B-N coatings for $1 \mathrm{~h}$ at $600^{\circ} \mathrm{C}, 700^{\circ} \mathrm{C}$, and $800^{\circ} \mathrm{C}$, respectively. The oxidation products on the oxidized specimens were characterized by XRD analysis. The fractured SEM observations were conducted to investigate the oxide scale formed on the coatings after oxidation. The potentiodynamic polarization curves for the $\mathrm{Si}$ specimens with and without coatings were obtained to investigate the corrosion performance of the Cr-Ti-B-N coatings utilizing a potentiostat (Versastat 4 ) in a $3.5 \mathrm{wt} . \%$ sodium chloride $(\mathrm{NaCl})$ solution at room temperature. $\mathrm{An} \mathrm{Ag} / \mathrm{AgCl}$ and platinum (Pt) mesh were used as a reference electrode and a counter electrode, respectively.

\section{Results and discussion}

\subsection{Chemical composition and microstructure}

By utilizing the hybrid coating system combining HIPIMS+ and DC power magnetron sputtering, dense and adherent Cr-Ti-B-N coatings were successfully deposited. By changing the HIPIMS+ generator power and the DC pulse power applied on the $\mathrm{TiB}_{2}$ and $\mathrm{Cr}$ cathodes $\left(\mathrm{P}_{\mathrm{TBB} 2}, \mathrm{P}_{\mathrm{Cr}}\right)$, respectively, coatings with various $\mathrm{Cr} / \mathrm{Ti}$ ratio and $\mathrm{B}$ contents were fabricated. The chemical compositions of the Cr-Ti-B-N coatings were obtained by XPS analysis, as summarized in Table 3. It can be seen that the $\mathrm{Cr}$ content increased 
Table 3. Chemical compositions of the Cr-Ti-B-N coatings for various cathode power of $\mathrm{TiB}_{2}$ and $\mathrm{Cr}$ targets by XPS analysis along with the calculated chemical formula

\begin{tabular}{|c|c|c|c|c|c|c|c|}
\hline \multirow{2}{*}{ Sample } & \multicolumn{2}{|c|}{ Synthesis conditions } & \multicolumn{5}{c|}{ Chemical composition (at. \%) } \\
\cline { 2 - 8 } & $\mathrm{P}_{\mathrm{TiB} 2}(\mathrm{~kW})$ & $\mathrm{P}_{\mathrm{Cr}}(\mathrm{kW})$ & $\mathrm{Cr}$ & $\mathrm{Ti}$ & $\mathrm{B}$ & $\mathrm{N}$ & Film stoichiometry \\
\hline $\mathrm{A} 0$ & 0.8 & 0.2 & 10.6 & 14.3 & 28.9 & 46.2 & $\mathrm{CrTi}_{1.3} \mathrm{~B}_{2.7} \mathrm{~N}_{4.3}$ \\
\hline $\mathrm{A} 1$ & 0.8 & 0.4 & 20.6 & 12.1 & 23.1 & 44.2 & $\mathrm{CrTi}_{0.6} \mathrm{~B}_{1.1} \mathrm{~N}_{2.1}$ \\
\hline $\mathrm{A} 2$ & 0.8 & 0.6 & 23.5 & 11.1 & 21.5 & 43.9 & $\mathrm{CrTi}_{0.5} \mathrm{~B}_{0.8} \mathrm{~N}_{1.8}$ \\
\hline $\mathrm{A} 3$ & 0.8 & 0.8 & 26 & 8.9 & 19.7 & 45.4 & $\mathrm{CrTi}_{0.3} \mathrm{~B}_{0.8} \mathrm{~N}_{1.7}$ \\
\hline $\mathrm{A} 4$ & 0.6 & 0.8 & 35.3 & 5.2 & 12.9 & 46.6 & $\mathrm{CrTi}_{0.1} \mathrm{~B}_{0.4} \mathrm{~N}_{1.3}$ \\
\hline A5 & 0.2 & 0.8 & 41.6 & 2.2 & 5.9 & 50.3 & $\mathrm{CrTi}_{0.1} \mathrm{~B}_{0.1} \mathrm{~N}_{1.2}$ \\
\hline
\end{tabular}

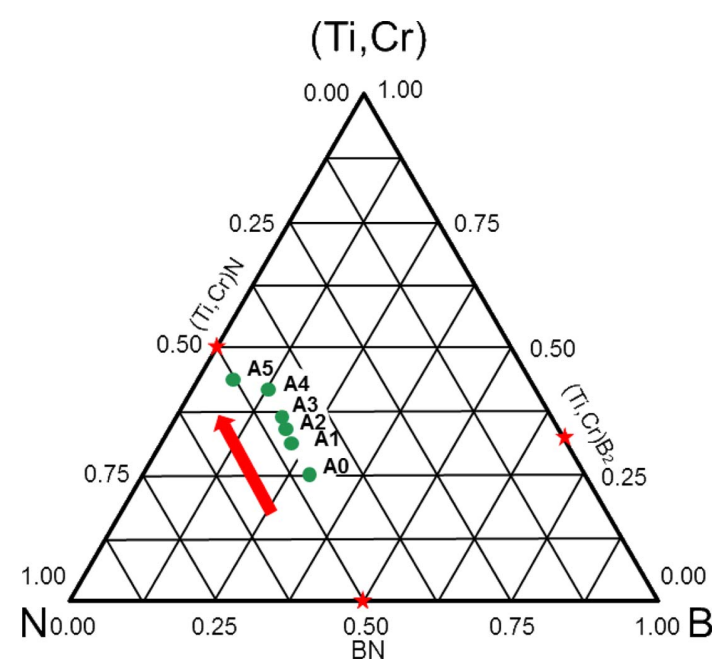

Fig. 2. Chemical compositions (at. \%, analyzed by XPS) of the Cr-Ti-B-N coatings within the simplified Ti (Cr)-B-N triangular phase diagram (adapted from [ ]).

with increase of the $\mathrm{Cr}$ target power and decrease of the $\mathrm{TiB}_{2}$ power while the $\mathrm{Ti}$ and $\mathrm{B}$ content exhibited the decreasing tendency. The $\mathrm{N}$ content remained almost constant. Fig. 2 shows the coating composition in the simplified $\mathrm{Ti}(\mathrm{Cr})-\mathrm{B}-\mathrm{N}$ triangular phase diagram. Here the summation of $\mathrm{Ti}(\mathrm{Cr})$ content was simplified as $\mathrm{Ti}$ because $\mathrm{Ti}$ and $\mathrm{Cr}$ elements can be dissolved each other in the nitride and boride phases. All the points (A0-A5) are located on or close to the ( $\mathrm{Ti}, \mathrm{Cr}$ ) $\mathrm{N}-\mathrm{BN}$ line. The coatings in this study should possess the quasi-binary ( $\mathrm{Ti}, \mathrm{Cr}) \mathrm{N}-\mathrm{BN}$ phase structure, which will be further investigated by the XRD and TEM analysis. In order to investigate the bonding status of the $\mathrm{Cr}, \mathrm{Ti}, \mathrm{B}$, and $\mathrm{N}$ elements in the coatings, the XPS results of the Cr-Ti-B-N coatings with different $\mathrm{Cr}$ contents were further analyzed. Fig. 3a-3d presents the XPS spectra near binding energies of $\mathrm{Cr} 2 p$, Ti $2 p, \mathrm{~B} 1 s$ and $\mathrm{N} 1 s$, respectively. For $\mathrm{Cr} 2 p$ region (Fig. $3 \mathrm{a}$ ), the $2 p 3 / 2$ and $2 p 1 / 2$ peak duplets were observed. The $\mathrm{Cr} 2 p 3 / 2$ can be decon- voluted into three sub peaks, with center positions at about $574.8 \mathrm{eV}^{27)}, 575.8 \mathrm{eV}^{27)}$ and $579.1 \mathrm{eV}^{28)}$, which correspond to those reported for $\mathrm{Cr}_{2} \mathrm{~N}, \mathrm{CrN}$ and $\mathrm{Cr}-\mathrm{O}$ compound, respectively. For Ti $2 p$ region (Fig. 3b), the Ti $2 p 3 / 2$ peak can be divided into two sub-peaks: Ti-N at $455.8 \mathrm{eV}^{29)}$ and Ti-O at $458.5 \mathrm{eV}^{30)}$. The B $1 s$ region in Fig. $3 \mathrm{c}$ can be mainly attributed to a $\mathrm{BN}$ formation. Also minor sub-peaks corresponding to B$\mathrm{O}$ and $\mathrm{Cr}-\mathrm{B}$ species were detected. In the $\mathrm{N} 1 s$ region, three sub-peaks corresponding to $\mathrm{TiN}, \mathrm{CrN}$, and $\mathrm{BN}$ were observed ${ }^{31-33)}$. With increase of $\mathrm{Cr}$ and decrease of $\mathrm{Ti}$ and $\mathrm{B}$ from coating $\mathrm{A} 1$ to $\mathrm{A} 5$, it can be seen that the intensity of $\mathrm{Cr}-\mathrm{N}$ peak $\left(\mathrm{CrN}, \mathrm{Cr}_{2} \mathrm{~N}\right)$ increased (Fig. 3a) while the Ti-N and B-N peaks (Fig. $3 \mathrm{~b}$ and Fig. 3c) decreased. Especially the decrease of $\mathrm{BN}$ species indicated the coatings are transforming from $\mathrm{Ti}(\mathrm{Cr}) \mathrm{N}-\mathrm{BN}$ composite to $\mathrm{Ti}$ (Cr) N solid solutions.

Fig. 4 shows the X-ray diffraction patterns of Ti-B$\mathrm{N}$ and Cr-Ti-B-N coatings deposited onto $\mathrm{Si}$ wafer substrates at various $\mathrm{P}_{\mathrm{TiB} 2}: \mathrm{P}_{\mathrm{Cr}}$ ratios. When the power of the $\mathrm{Cr}$ target is $0 \mathrm{~W}$, Ti-B-N coating was obtained, which exhibited quasi-amorphous XRD pattern. As the $\mathrm{Cr}$ was incorporated into the Ti-B-N coatings by increasing the $\mathrm{Cr}$ target power, XRD peaks were observed when the $\mathrm{Cr}$ content was larger than 20.6 at.\% (A0-A5), below which the coatings exhibited amorphous characteristics (A0). With increase of the $\mathrm{Cr}$ elements, the XRD peaks sharpened, which indicated the better crystallinity and larger grains in the coatings. The diffraction pattern of Ti-Cr-B-N coatings exhibited $\mathrm{B} 1 \mathrm{NaCl}$ crystal structure with random orientations of (111), (200), (220), and (311) crystal planes. By comparing the lattice spacings of the standard $\mathrm{TiN}$ and $\mathrm{CrN}$ phases with those in Fig. 4 , it can be seen that the XRD peaks can be attributed to those of the $\mathrm{Ti}(\mathrm{Cr}) \mathrm{N}$ solid solutions. No other species were detected. By combining the XPS results in Fig. 3, it can be speculated that the 

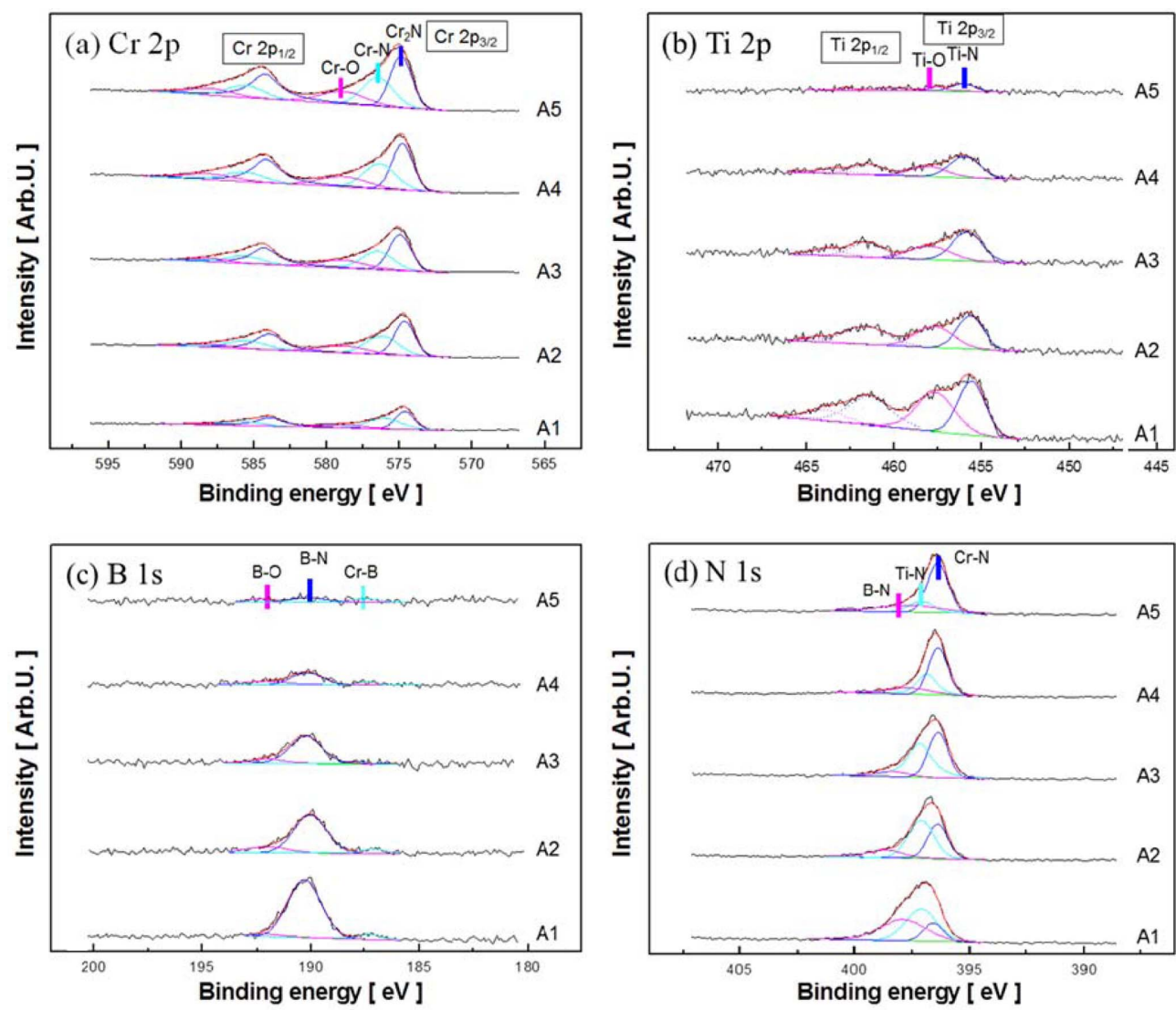

Fig. 3. Fitted XPS spectra of (a) Cr 2p, (b) Ti 2p, (c) B 1s and (d) N 1s for the Cr-Ti-B-N coatings with various chemical compositions.

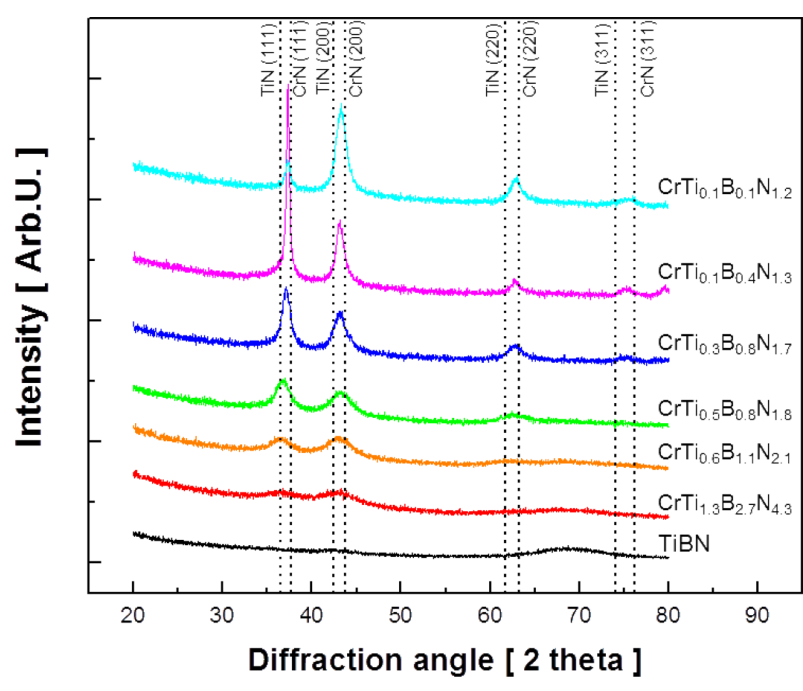

Fig. 4. XRD patterns of the various Cr-Ti-B-N coatings.

Cr-Ti-B-N coatings were nanocomposites containing $\mathrm{Ti}(\mathrm{Cr}) \mathrm{N}$ nanocrystals and amorphous $\mathrm{BN}$ phase at high $\mathrm{Cr}$ content while the coatings were quasiamorphous at low $\mathrm{Cr}$ content. This is easy to understand. With high $\mathrm{Cr}$ content in the coatings, the Cr-Ti-B-N coatings contain low content of $\mathrm{BN}$ species. The coatings are mainly solid solution of $\mathrm{Ti}(\mathrm{Cr}) \mathrm{N}$ phases, which are well crystallized. With decrease of $\mathrm{Cr}$ content in the coatings, the fraction of BN species increased. Here the $\mathrm{BN}$ species are amorphous and can not be detected by XRD. The BN phase and Ti (Cr) $\mathrm{N}$ phase are not soluble to each other. When the $\mathrm{BN}$ species are incorporated into the $\mathrm{Ti}(\mathrm{Cr}) \mathrm{N}$ coating, they will segregated into the grain boundaries and limit the growth of the $\mathrm{Ti}(\mathrm{Cr}) \mathrm{N}$ grains, which resulted in the formation of nc-Ti (Cr) N/a-BN nanocomposite. With further increasing the $\mathrm{BN}$ content, the coating will transform into amorphous by incorporation of the $\mathrm{Ti}(\mathrm{Cr}) \mathrm{N}$ species into the amorphous BN phase. Similar results have been reported in the Ti-B-N system in ref..$^{8-11}$.

To further determine the microstructure of the coatings, the Cr-Ti-B-N coatings were investigated by TEM analysis. Fig. 5-7 shows the cross-sectional bright-field (BF-) and dark field (DF-) TEM images, SADP (selected area diffraction pattern) and the corresponding high-resolution TEM (HRTEM) images for the $\mathrm{CrTi}_{1.3} \mathrm{~B}_{2.7} \mathrm{~N}_{4.3}$ (A0), $\operatorname{CrTi}_{0.5} \mathrm{~B}_{0.8} \mathrm{~N}_{1.8}$ (A2), $\mathrm{CrTi}_{0.1} \mathrm{~B}_{0.4} \mathrm{~N}_{1.3}$ (A4) coatings, respectively. It can be seen that coating A0 exhibited fully amorphous microstructure (Fig. 5). In Fig. 6a, the BF-TEM and 


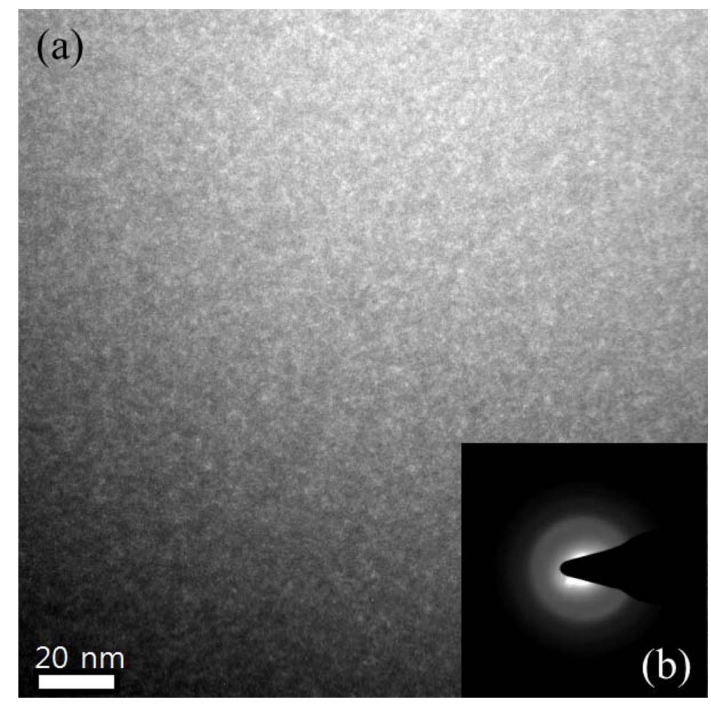

Fig. 5. Cross-sectional TEM images of the $\mathrm{CrTi}_{1.3} \mathrm{~B}_{2.7} \mathrm{~N}_{4.3}$ coatings (a) dark-field image from the central region (b) selected area diffraction pattern (SADP).

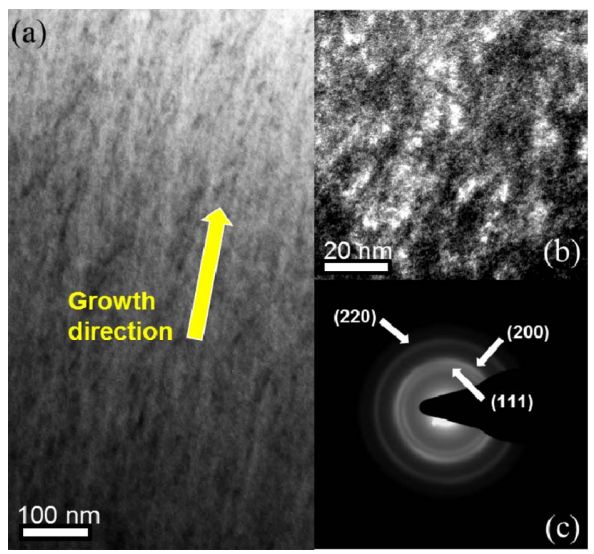

DF-TEM images revealed the coatings were nanocolumnar microstructure composed of fine nanograins while the SADP pattern indicated diffraction rings corresponding to $\mathrm{Ti}(\mathrm{Cr}) \mathrm{N}$ FCC nanocrystals. In Fig. $6 \mathrm{~b}$, the HRTEM images indicated nanocomposite microstructure with nano-sized crystallites of 2-3 nm being enveloped by an amorphous phase, which were distinguished from each other by lattice fringe contrast. The nanocrystals revealed (111) and (200) lattice fringes of FCC $\mathrm{Ti}(\mathrm{Cr}) \mathrm{N}$ phase. In case of $\mathrm{CrTi}_{0.1} \mathrm{~B}_{0.4} \mathrm{~N}_{1.3}$ coating (Fig. 7), the average size of the crystallites was significantly increased to 5-6 nm. Similar to the nanocomposite in Fig. 6, the nanocrystals are also enveloped by amorphous phase. Based on results from the XRD, XPS and TEM analyses, it is concluded that the Cr-Ti-B-N coatings with suitable $\mathrm{B}$ contents are nanocomposites consisting of nanosized (Ti, Cr) $\mathrm{N}$ crystallites embedded in an amorphous $\mathrm{BN}$ matrix.

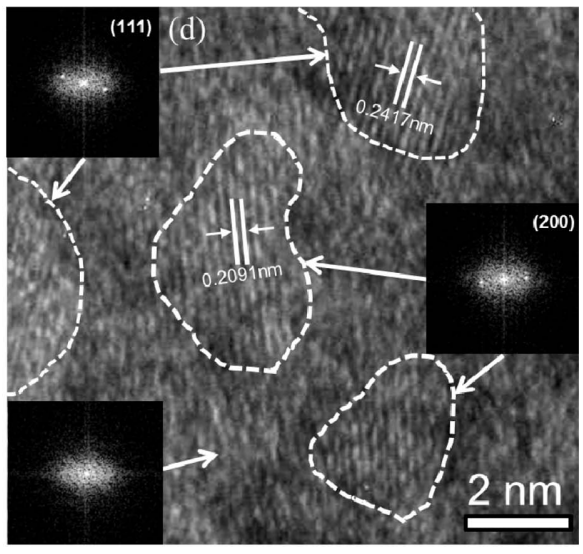

Fig. 6. Cross-sectional TEM images of the CrTi0.5B0.8N1.8 coatings (a) bright-field image (b) dark-field image from the central region (c) selected area diffraction pattern (SADP) (d) high-resolution TEM image and their FFT patterns (insets) corresponding to lattice fringes.
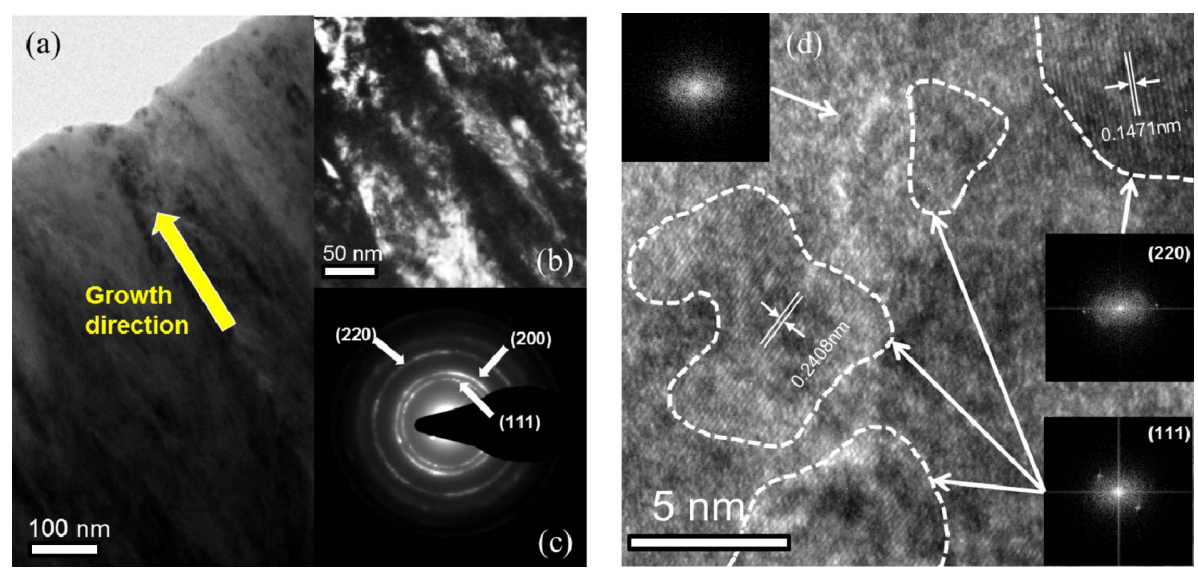

Fig. 7. Cross-sectional TEM images of the $\mathrm{CrTi}_{0.2} \mathrm{~B}_{0.4} \mathrm{~N}_{1.3}$ coating (a) bright-field image (b) dark-field image from the central region (c) selected area diffraction pattern (SADP) (d) high-resolution TEM image and the FFT patterns (insets) corresponding to the lattice fringes. 


\subsection{Mechanical properties of the $\mathrm{Cr}$-Ti-B-N coatings}

Fig. 8 presents the hardness and friction coefficient of Cr-Ti-B-N coatings with various $\mathrm{Cr}$ contents. The hardness of the Cr-Ti-B-N coatings increased from $\sim 14 \mathrm{GPa}$ at 10.6 at. $\% \mathrm{Cr}$ to a maximum value of approximately $\sim 41 \mathrm{GPa}$ at 35.3 at.\% $\mathrm{Cr}$, and then decreased with further increase of $\mathrm{Cr}$ content about $26 \mathrm{GPa}$ at 41.6 at.\% $\mathrm{Cr}$. The large increase in hardness of Cr-Ti-B-N is most likely the result of nanocomposite microstructure, which combines grain boundary hardening created by strong cohesive energy of interphase boundaries and Hall-Petch relationship derived from crystal size refinement. By the suitable percolation of amorphous $\mathrm{BN}$ around the $(\mathrm{Cr}, \mathrm{Ti}) \mathrm{N}$ nanocrystals, the coatings can obtain maximum hardness. Increase or decrease of the $\mathrm{Cr}$ content in the coatings, the amorphous layer around the nanocrystals thickens or thinner. The ideal interactions between the nanocrystallites and amorphous phase can be lost.

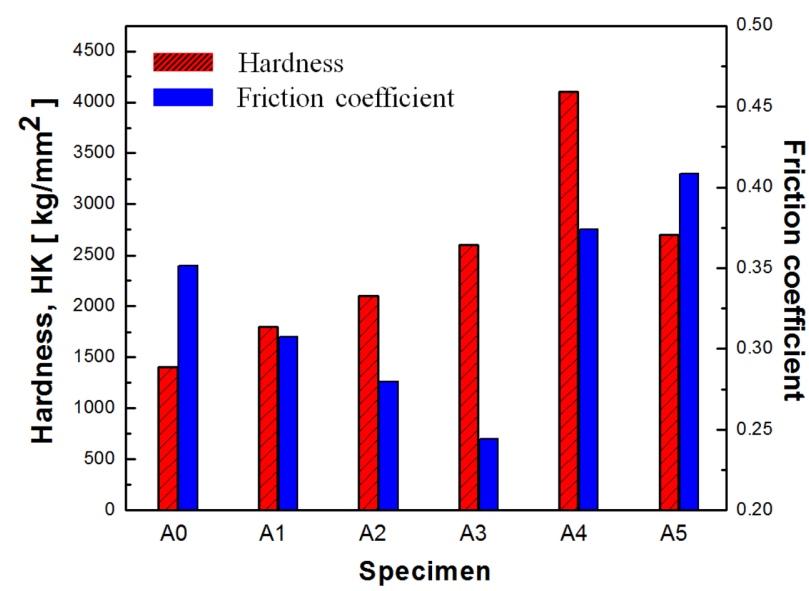

Fig. 8. Hardness and friction coefficient of the various Cr-Ti-B-N coatings.

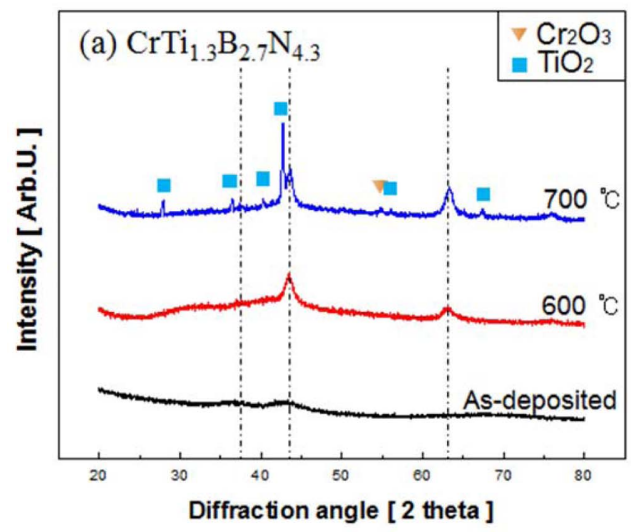

Especially, the coatings with coarse grains or amorphous microstructure will exhibit much lower hardness. In this study, the microhardness decreased again to $\sim 27 \mathrm{GPa}$ for the $\mathrm{CrTi}_{0.1} \mathrm{~B}_{0.1} \mathrm{~N}_{1.2}$ coating with further increase in the $\mathrm{Cr}$ content after achieving the maximum microhardness, which is considered to be due to the grain size effect.

The friction coefficients of the Cr-Ti-B-N coatings were evaluated using a steel ball (diameter $6.34 \mathrm{~mm}$, $700 \mathrm{H}_{\mathrm{v}}$ 0.2) as a counterpart material. Fig. 8 also shows the friction coefficient of the Cr-Ti-B-N coatings as a function of $\mathrm{Cr}$ content under a normal load of $5 \mathrm{~N}$ at ambient temperature $\left(\approx 20^{\circ} \mathrm{C}\right)$ and a relative humidity of $25 \sim 30 \%$. As the $\mathrm{Cr}$ content increased, the mean friction coefficient of the Cr-Ti-B-N coatings decreased from $\sim 0.36$ to $\sim 0.24$ for the $\mathrm{CrTi}_{0.3} \mathrm{~B}_{0.8} \mathrm{~N}_{1.7}$ coating. The decrease in friction coefficient at $\mathrm{CrTi}_{0.3} \mathrm{~B}_{0.8} \mathrm{~N}_{1.7}$ might be caused by multi-action between amorphous boron-nitride (a-BN) and the additional self-lubricant layer, such as $\mathrm{Cr}_{2} \mathrm{O}_{3}$. Further increase in the $\mathrm{Cr}$ content resulted in the increase of the friction coefficient to $\sim 0.41$. With increase of $\mathrm{Cr}$ content in the coatings, the content of a-BN decreased simultaneously, which resulted in the increase of friction coefficient. We can know the friction coefficient depend on a-BN phase more than the $\mathrm{Cr}$ contents. The microhardness and friction coefficient showed that $\mathrm{CrTi}_{0.2} \mathrm{~B}_{0.4} \mathrm{~N}_{1.3}$ coating has comparatively high mechanical properties.

\subsection{Oxidation behaviour}

The oxidation behavior of the Cr-Ti-B-N coating synthesized was also examined in this work. Fig. 9a and Fig. 9(b) shows the XRD patterns of the isothermal oxidation results of the $\mathrm{CrTi}_{1.3} \mathrm{~B}_{2.7} \mathrm{~N}_{4.3}$ and $\mathrm{CrTi}_{0.1} \mathrm{~B}_{0.4} \mathrm{~N}_{1.3}$ coatings at $600^{\circ} \mathrm{C}$ and $700^{\circ} \mathrm{C}$ for 1 hour,

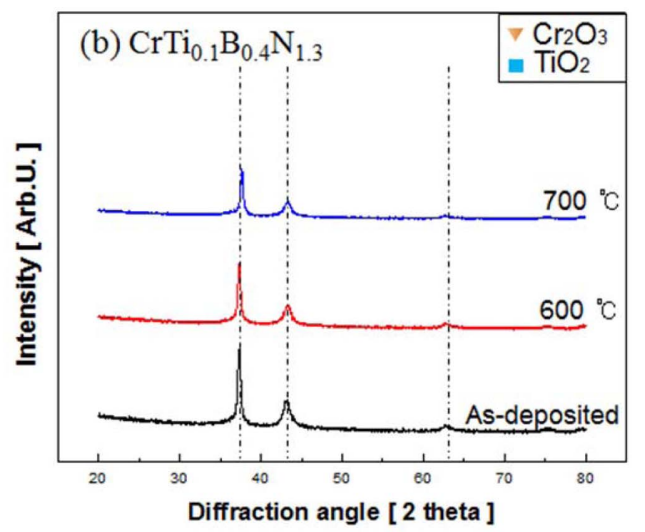

Fig. 9. XRD patterns of the $\mathrm{CrTi}_{1.3} \mathrm{~B}_{2.7} \mathrm{~N}_{4.3}$ and $\mathrm{CrTi}_{0.1} \mathrm{~B}_{0.4} \mathrm{~N}_{1.3}$ coatings after oxidation for $1 \mathrm{~h}$ at $600^{\circ} \mathrm{C}, 700^{\circ} \mathrm{C}$ and $800^{\circ} \mathrm{C}$, respectively. 


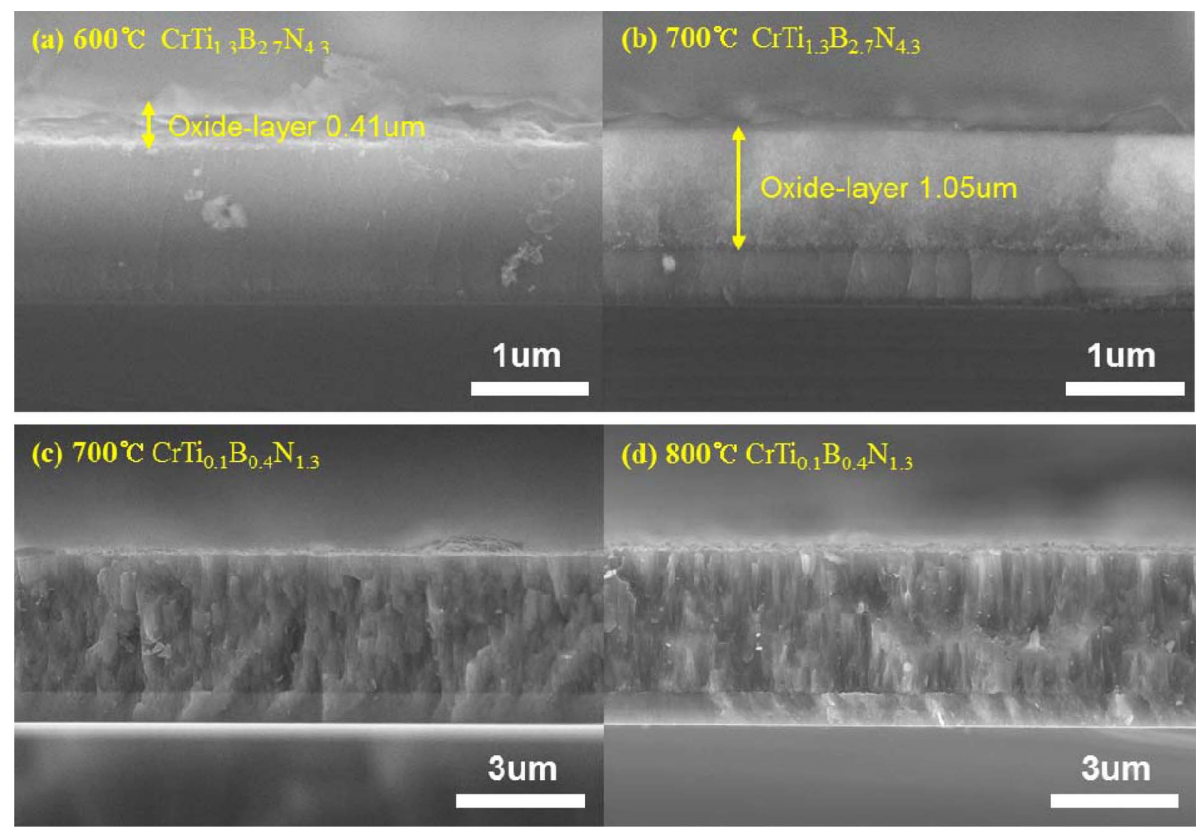

Fig. 10. Cross-sectional SEM images of the coatings after isothermal oxidation, (a), (b) $\mathrm{CrTi}_{1.3} \mathrm{~B}_{2.7} \mathrm{~N}_{4.3}$ coating at 600 , $700^{\circ} \mathrm{C}$ for $1 \mathrm{~h}$, respectively. (c), (d) $\mathrm{CrTi}_{0.1} \mathrm{~B}_{0.4} \mathrm{~N}_{1.3}$ coating at $700,800^{\circ} \mathrm{C}$ for $1 \mathrm{~h}$, respectively.

respectively. In Fig. 9(a), the XRD spectra after oxidation at $600^{\circ} \mathrm{C}$ did not reveal any apparent differences as compared to the coating before oxidation test. After $700^{\circ} \mathrm{C}$, peaks of $\mathrm{TiO}_{2}$ and $\mathrm{Cr}_{2} \mathrm{O}_{3}$ were detected, as oxidation products. In Fig. 9(b), strong peaks of (Cr, Ti) N (111), (200) and (220) planes were detected in the $\mathrm{CrTi}_{0.1} \mathrm{~B}_{0.4} \mathrm{~N}_{1.3}$ coatings. After oxidation at $600^{\circ} \mathrm{C}$ and $700^{\circ} \mathrm{C}$, while no obvious oxide peaks can be observed. Fig. 9(a) and Fig. 9(b) shows that the Cr-Ti-B-N coatings exhibited better oxidation resistance As $\mathrm{Cr} / \mathrm{Ti}$ ratio increased in the coatings. Fig. 10 shows fractured cross-sectional SEM images of the Cr-Ti-B-N coatings after oxidation for 1 hour at $600^{\circ} \mathrm{C}, 700^{\circ} \mathrm{C}$, and $800^{\circ} \mathrm{C}$, respectively. In Fig. 10(a) and Fig. 10(b), continuous and homogenous oxide scale with thickness of $\sim 0.41$ and $\sim 1.05 \mu \mathrm{m}$ formed on the $\mathrm{CrTi}_{1.3} \mathrm{~B}_{2.7} \mathrm{~N}_{4.3}$ coatings after oxidation $600^{\circ} \mathrm{C}$ and $700^{\circ} \mathrm{C}$, respectively. In Fig. 10 (c) and Fig. 10(d), no obvious oxide layer can be observed on the $\mathrm{CrTi}_{0.1} \mathrm{~B}_{0.4} \mathrm{~N}_{1.3}$ coatings after oxidation $700^{\circ} \mathrm{C}$ and $800^{\circ} \mathrm{C}$, respectively. The observations on the oxide layer confirmed that the $\mathrm{CrTi}_{0.1} \mathrm{~B}_{0.4} \mathrm{~N}_{1.3}$ coatings exhibited better oxidation resistance than the $\mathrm{CrTi}_{1.3} \mathrm{~B}_{2.7} \mathrm{~N}_{4.3}$ coatings. The reason can be explained by the higher $\mathrm{Cr}$ content in the former. With higher $\mathrm{Cr} / \mathrm{Ti}$ ratio in the coatings, $\mathrm{Cr}$ is much easier to diffuse out to the coating surface to form a dense $\mathrm{Cr}_{2} \mathrm{O}_{3}$ oxide layer on the surface when the oxidation starts, and the formed $\mathrm{Cr}_{2} \mathrm{O}_{3}$ oxide layer prohibits the ingress of oxygen into the coatings, as a protective layer. With low $\mathrm{Cr} /$
Ti ratio in the coatings more $\mathrm{TiO}_{2}$ oxide scale was formed on the coating surface, which is relatively porous, and can not play a perfect roles as a diffusion barrier against further oxidations as compared with pure $\mathrm{Cr}_{2} \mathrm{O}_{3}$ oxide layer. Therefore, the oxide layer mainly of $\mathrm{TiO}_{2}$ will thicken, which result in the continuing oxidation of the coatings. The higher $\mathrm{Cr}$ content in the coatings is favor of the oxidation resistance.

\subsection{Corrosion behaviour}

The potentiodynamic polarization tests were conducted

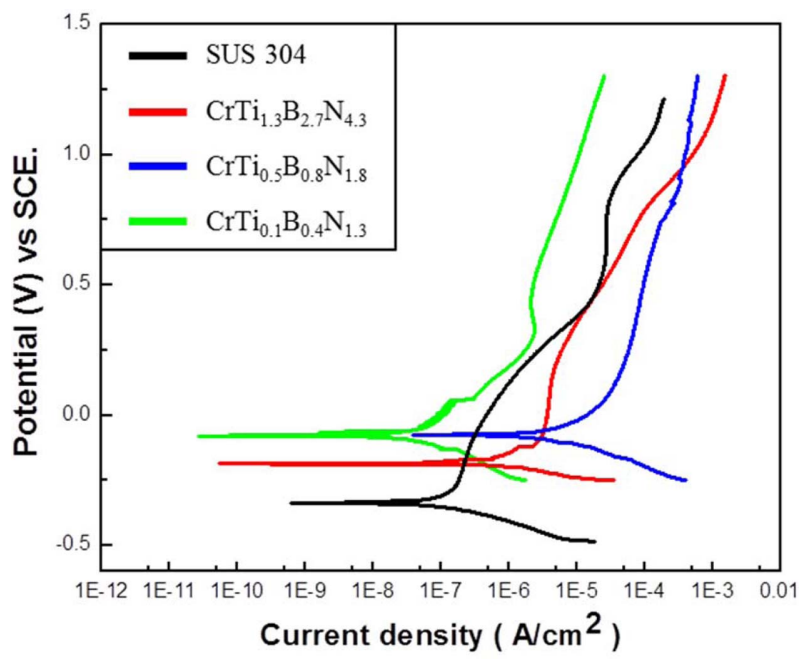

Fig. 11. The potentiodynamic polarization curves of the Cr-Ti-B-N coatings, as well as the AISI 304 substrate, in $3.5 \mathrm{wt} \% \mathrm{NaCl}$ aqueous solution. 
Table 4. Corrosion results by potentiodynamic polarization curves obtained in $3.5 \mathrm{wt}$ \% $\mathrm{NaCl}$ solution

\begin{tabular}{|c|c|c|c|c|}
\hline & SUS 304 & $\operatorname{CrTi}_{1.3} \mathrm{~B}_{2.7} \mathrm{~N}_{4.3}$ & $\operatorname{CrTi}_{0.5} \mathrm{~B}_{0.8} \mathrm{~N}_{1.8}$ & $\operatorname{CrTi}_{0.1} \mathrm{~B}_{0.4} \mathrm{~N}_{1.3}$ \\
\hline $\mathrm{I}_{\text {Corr }}\left(\mathrm{A} / \mathrm{cm}^{2}\right)$ & $6.26 \times 10^{-10}$ & $5.32 \times 10^{-11}$ & $3.91 \times 10^{-8}$ & $2.71 \times 10^{-11}$ \\
\hline $\mathrm{E}_{\text {Corr }}(\mathrm{V}$ vs. $\mathrm{Ag} / \mathrm{AgCl})$ & -0.337 & -0.186 & -0.076 & -0.079 \\
\hline
\end{tabular}

to investigate the corrosion behavior of the Cr-Ti-B$\mathrm{N}$ coatings. Fig. 11 shows the polarization curves of the AISI 304 specimens with and without coatings. Table 4 lists the respective corrosion current densities $\left(\mathrm{i}_{\text {Corr }}\right)$ and the corrosion potentials $\left(\mathrm{E}_{\text {Corr }}\right)$. Corrosion current was calculated using Tafel equation ${ }^{34)}$. As compared with the AISI 304 specimens, the specimens coated with $\mathrm{CrTi}_{1.3} \mathrm{~B}_{2.7} \mathrm{~N}_{4.3}$ and $\mathrm{CrTi}_{0.5} \mathrm{~B}_{0.8} \mathrm{~N}_{1.8}$ exhibit much higher corrosion potential, which means it was more difficult for corrosion occurring by applying $\mathrm{Cr}$ Ti-B-N coatings. The specimen coated with $\mathrm{CrTi}_{0.1} \mathrm{~B}_{0.4} \mathrm{~N}_{1.3}$ exhibits much lower corrosion current density and much higher corrosion potential compare to AISI 304 specimen, which means the coating possesses better corrosion resistance and protects the substrate from corrosive media. As $\mathrm{Cr}$ content increases in the coating dense $\mathrm{Cr}_{2} \mathrm{O}_{3}$ protective layer was much easier to be formed on the coating surface during the chemical attack, which passivates the surface and prevents further corrosion attack. In addition, the $\mathrm{Cr}-$ Ti-B-N coatings are very dense in this study, with no pores where the corrosive medium passing through, which is the merit of HIPIMS technique. This could also provide good protection on the substrate.

\section{Conclusion}

Cr-Ti-B-N coatings were deposited on AISI 304 stainless steel and single crystalline $\mathrm{Si}$ wafer substrates using a hybrid coating system utilizing a HIPIMS+ and a DC pulse magnetron sputtering from a $\mathrm{TiB}_{2}$ and $\mathrm{Cr}$ target in an $\mathrm{Ar}-\mathrm{N}_{2}$ atmosphere, respectively. TEM, XPS, XRD analyses revealed that the synthesized Cr-Ti-B-N coatings were amorphous at high $\mathrm{Ti} / \mathrm{Cr}$ ratio and high $\mathrm{B}$ content. They evolved into nanocomposites consisting of solid-solution $(\mathrm{Cr}$, Ti) $\mathrm{N}$ nano-crystallites embedded in an amorphous $\mathrm{BN}$ matrix with increase of $\mathrm{Cr}$ content. Further increasing the $\mathrm{Cr}$ content resulted in the grain growth in the coatings. Correspondingly, as the chromium content increased, the hardness of Cr-Ti-B-N coatings increased and reached the maximum value of approximately $41 \mathrm{GPa}$ at 41.6 at.\% $\mathrm{Cr}$ content and then decreased with further increasing the $\mathrm{Cr}$ content. The friction coefficient exhibited similar tendencies.
The $\mathrm{CrTi}_{0.3} \mathrm{~B}_{0.8} \mathrm{~N}_{1.7}$ coating showed the lowest mean friction coefficient of 0.24 against a steel ball. The oxidation resistance of the Cr-Ti-B-N coatings was significantly dependent on the $\mathrm{Cr}$ content of the coatings. Better oxidation behavior was observed for the coatings with higher $\mathrm{Cr}$ content. The $\mathrm{Cr}-\mathrm{Ti}-\mathrm{B}-\mathrm{N}$ coatings significantly improved the corrosion resistance of the AISI 304 stainless steels.

\section{Acknowledgement}

The work was supported by a grant from the Fundamental R\&D Program for Core Technology of Materials funded by the Ministry of Knowledge Economy, Republic of Korea.

\section{References}

1. S. A. Barnett, A. Madan, Physics World, 11 (1998) 45.

2. S. Veprek, A. Niederhofer, K. Moto, T. Bolom, H. D. Männling, P. Nesladek, G. Dollinger, A. Bergmaier, Surf. Coat. Technol., 133 (2000) 152.

3. K. W. Lee, Y.-H. Chen, Y. W. Chung, L. M. Keer, Surf. Coat. Technol., 177 (2004) 591.

4. D. V. Shtansky, S. A. Kulinich, E. A. Levashov, A. N. Sheveiko, F. V. Kiriuhancev, J. J. Moore, Thin Solid Films, 330 (2002) 420-421.

5. D. V. Shtansky, F. V. Kiryukhantsev-Korneev, A. N. Sheveiko, I. A. Bashkova, O. V. Malochkin, E. A. Levashov, N. B. D'yakonova, I. V. Lyasotsky, Phys. Solid State, 47 (2005) 252.

6. M. Audronis, P. J. Kelly, R. D. Arnell, A. Leyland, A. Matthews, Surf. Coat. Technol., 200 (2005) 1366.

7. R. J. Brotherton, H. Steinberg, Progress in Boron Chemistry, vol.2, Pergamon Press, Oxford, (1970) 173.

8. C. Mitterer, M. Rauter, P. Rödhammer, Surf. Coat. Technol., 41 (1990) 351.

9. M. Tamura, H. Kubo, Surf. Coat. Technol., 54-55 (1992) 255-260.

10. E. Broszeit, B. Matthes, W. Herr, K. H. Kloos, Surf. Coat. Technol., 58 (1993) 29.

11. W. Gissler, Surf. Coat. Technol., 68-69 (1994) 556.

12. H. Karner, J. Laimer, H. Stori, P. Rodnammer, Surf. Coat. Technol., 39-40 (1991) 263. 
13. J. M. Antunes, A. Cavaleiro, L. F. Menezes, M. I. Simoes, J. V. Fernandes, Surf. Coat. Technol., 149 (2002) 27.

14. C. Mitterer, J. Solid State Chem., 133 (1997) 279291.

15. B. Rother, H. Kappl, Surf. Coat. Technol., 73 (1995) 14.

16. B. Rother, H. Kappl, Surf. Coat. Technol., 96 (1997) 163.

17. S. M. Aouadi, F. Namavar, E. Tobin, N. Finnegan, R. T. Haasch, R. Nilchiani, J. A. Turner, S. L. Rohde, J. Appl. Phys., 91 (2002) 1040.

18. P. V. Kiryukhantsev-Korneev, J. F. Pierson, M. I. Petrzhik, M. Alnot, E. A. Levashov, D. V. Shtansky, Thin Solid Films, 517 (2009) 2675-2680.

19. J. Lin, B. Mishra, J. J. Moore, M. Pinkas, W. D. Sproul, Surf. Coat. Technol., 203 (2008) 588-593.

20. D. V. Shtansky, A. N. Sheveiko, M. I. Petrzhik, E. Kiryukhantsev-Korneev, E. A. Levashov, A. Leyland, A. L. Yerokhin, A. Matthews, Surf. Coat. Technol., 200 (2005) 208-212.

21. D. V. Shtansky, P. V. Kiryukhantsev-Komeev, A. N. Sheveyko, A. E. Kutyrev, E. A. Levashov, Surf. Coat. Technol., 202 (2007) 861-865.

22. J. Paulitsch, M. Schenkel, T. Zufrass, P. H. Mayrhofer,
W. D. Munz, Thin Solid Films, 518 (2010) 55585564.

23. J. L. Lin, N. Y. Zhang, W. D. Sproul, J. J. Moore, Surf. Coat. Technol., 206 (2012) 3283-3290.

24. J. L. Lin, W. D. Sproul, J. J. Moore, Surf. Coat. Technol., 206 (2012) 2474-2483.

25. J. L. Lin, W. D. Sproul, J. J. Moore, S. Lee, S. Myers, Surf. Coat. Technol., 205 (2011) 3226-3234.

26. J. Paulitsch, P. H. Mayrhofer, W. D. Munz, M. Schenkel, Thin Solid Films, 517 (2008) 1239-1244.

27. O. Nishimura, K. Yabe, M. Iwaki, J. Electron Spectrosc. Relat. Phemon., 49 (1989) 335

28. R. Merryfield, M. McDaniel, G. J. Parks, Catal., 77 (1982) 348.

29. Y. M. Shulg'a, V. N. Troitskii, M. I. Aivazov, Y. G. Borodk'o, Zh. Neorg. Khimii, 21 (1976) 2621.

30. W. E. Slinkard, P. B. Degroot, J. Catal., 68 (1981) 423.

31. M. Romand, M. Roubin, Analusis, 4 (1976) 309.

32. B. M. Biwer, S. L. Bernasek. J. Electron Spectrosc. Relat. Phemon., 40 (1986) 339.

33. K. Hamrin, G. Johansson, U. Gelius, C. Nordling, K. Siegbahn, Phys. Scripta, 1 (1970) 277.

34. G. Rocchini, Corros. Sci., 37(6) (1995) 987-1003. 